Historic, archived document

Do not assume content reflects current scientific knowledge, policies, or practices. 

CONDENSED CATALOG OF

Nursery Stock

OFFERED BY

Home Nursery Co.

LIBERAL, MISSOURI

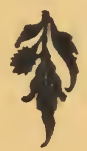

We pack and ship trees and plants to your post office or expree office at enclosed prices.

All of our trees and plants are inspected by a state officer and are free from disease or insects.

A health certificate accompanies every shipment.

All trees and plants sent out are absolutely true to name.

We do our own propogating, budding peach, apricot, nectorine and plum on peach seedlings, graft apple on French crab, pear on Keiffer seedlings.

Look over this list and select what you want. If not ready to order we will hold it for you for 25 per cent of purchase price.

Some people ask what age trees to plant. We recommend planting two year old trees in Kansas, Missouri and states north of this. Farther south, one or two year trees are planted to good success.

Look around and see what your neighbors planted and had best success with.

We are growing trees and plants as cheap as we can and justify ourselves for labor and expenses we are out; we will put our nursery stock up against any other nursery for low prices or quality of stock.

You will notice we do not grow as large assortment of trees or plants as some do, but after 17 years experience selling trees we think we know what will give best satisfaction over a large territory.

We pack all sock carefully, using straw and moss around roots, and burlap to protect tops of trees.

We pay parcel-post charges on all orders that are made out at each rate, express shipments are paid by purchaser.

We will prune trees back ready to set if requested to do so.

About tree salesmen: We have tried them out to our loss of money and valuable time and will not employ them any more.

We will put in extra trees or plants if you send us a few names of land owners with their post office address.

We will attempt to give a brief description of most stock we have to offer. Will appreciate your orders, large or small.

If you do not see what you want in this list, just write us 
asking where you can get it cheapest and we will do all we can for you, the charges will be 2 cents for postage only. We get catalogs on everything, from a baby carriage to steam ships.

\section{Apple Trees}

EARLY HARVEST-Fruit medium sized, greenish yellow, tender and juicy, ripens in July.

RED JUNE-Medium sized red apple, ripens ahead of Early Harvest.

RED ASTRACHAN-Fruit large for early apple, beautiful crimson color, very acidy, good cooker.

YELLOW TRANSPARENT-One of the best pale yellow apples; tree dwarfish, bears young and regular, ripens in July.

MAIDEN BLUSH-Rather large, sub acid, yellow, with some red on sunny side, flesh white and tender, good cooker.'

WEALTHY-Tree a thrifty grower, fruit best for home use. ripens in July.

JONATHAN-One of the best all-round apples, tree hardy and bears well, apple medium to large, flesh tender and juicy.

ROME BEAUTY-Large uniform shaded and striped, has a brilliant red background color; in eastern states is one of best apples grown, good quality and tender.

GRIMES GOLDEN-One of the best yellow apples grown, hardy in tree and bud, tree upright grower, bears full of golden apples of medium size, sub-acid late fall apple.

WOLF RIVER-Trees grow very large, has large fruit of only fair quality, is a pretty good show apple.

MINKLER-Trees irregular in shape, bears full, a good keeping winter apple, of good quality.

YORK IMPERIAL - Tree moderate grower, productive, fruit large lop-sided, fruit bright yellow on red ground, tender, juicy.

SIBERIAN CRAB - This is the small yellow crab that makes the delicious preserves, tree dwarfish, bears full and every year.

WHITNEY CRAB, No. 20-Tree thrifty, upright grower, fruit medium size, juicy and pleasant flavor, ripens in September.

FLORENCE CRAB-Large, handsome crimson, splashed with red, prolific tree and bears well, ripens in September.

GOLDEN SWEET-Best summer sweet apple, yellow, tender, tree good grower and bears well every two years, September apple.

BEN DAVIS-A good commercial apple with poor to fair quality. If you want apples every year set a few Ben Davis trees.

BLACK BEN DAVIS-Dark red winter apple, of Ben Davis type, but far better quality, good shipper and bears young.

DELICIOUS-Called Stark Delicious by some, one of the best red winter apples, keeps well and tree generally good bearer. Sweet, slightly touched with acid, pleasing delightful flavor.

MAMMOTH BLACK TWIG-A good large red or almost black winter apple, does best on high dry sandy soil, tree makes a fine orchard specimen and a good bearer, good for home or commercial use.

STAYMEN WINESAP-Improved Winesap, larger and better apple than Winesap, good cooker, keeps well, bears full of fine large red apples when others fail. 
ARKANSAS BLACK-A good red apple, in favored localities it is one of the best winter apples, keeps till April.

KING DAVID-Originated in the Boston mountains near Durham, Ark., is of Winesap type but some larger and trees grow larger and straight up, apples are dark red, white flesh, keeps well.

WINTER BANANA-Large greenish yellow winter apple, has banana flavor, a shy bearer in this locality, said to bear well in eastern or western states.

WINESAP - A medium sized red winter apple, trees grow irregular, bears well, keeps till March or later, flesh white, tender juicy, and when fully ripe it is one of the best flavored apples on the market.

MISSOURI PIPPIN-Medium sized red winter apple, has specks and splashes over it, tree bears young and annually, trees are dwarfish in habit, has peculiar smoky flavor that is relished by some.

GANO-A cross between Ben Davis and Black Ben Davis, not quite so good as black Ben Davis, tree looks like Ben Davis, apple is larger than either, white flesh, good commercial apple.

NORTH-WESTERN GREENING-Fruit medium to large, averaging from 10 to 12 ounces each, greenish yellow, very juicy, tender, tree hardy and good grower, apple best and latest keeper.

GENETON-A greenish yellow apple of medium size, has specks and stripes over surface, good juicy fall or early winter aple.

$$
\text { Price of Apple Trees Each } 25 \quad 100
$$

1 year old,18 to 24 inches high__._. $\$ \quad .12 \quad \$ 2.75 \quad \$ 10.00$

1 year old, 2 to 3 feet high

1 year old, 3 to 4 feet high___._-_ $\quad .20 \quad 4.75 \quad 18.00$

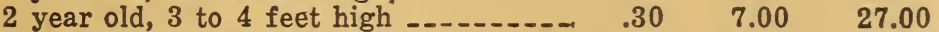

2 year old, 4 to 5 feet high....... $.40 \quad 9.00 \quad 35.00$

\section{Varieties of Peach Trees}

MAY FLOWER-First and best early peach, ripens about June 25 th, flesh almost white, semi-cling, hardy and productive.

ALEXANDER-Almost red early semi-cling, ripens after May Flower, solid for an early peach.

CARMEN-Freestone, early, large, creamy white, flesh ten. der and will produce peaches when others fail.

RED BIRD CLING-Another semi-cling, of best quality early peach, almost red, ripens just a little later than May Flower. tree hardy and a good commercial kind.

CRAWFORD'S EARLY-Fruit very large, oblong, skin yellow, with a fine red cheek, flesh yellow and juicy, productive, ripens last of August, freestone.

CRAWFORD'S LATE-About like Crawford's Early except two weeks later in ripening and some larger.

ELBERTA-Among peaches Elberta takes the lead for beauty, size and quality, a heavy bearer, one of the hardiest, as large as Crawford's Early and fully its equal in flavor and beauty, one of the finest yellow freestone peaches, ripens about August 15 th.

TRIUMPH-Ripens with Alexander, blooms late, a sure and abundant bearer, fruit of large size, very small pit, surface yellow, nearly covered with red, and dark crimson in the sun, flesh bright yellow, free when fully ripe. 
WONDERFUL-Large rich golden yellow, flesh yellow, rich, highly flavored, freestone, ripens in September.

J. H. HALE-Rich deep golden yellow, flesh solid as a cling yet a perfect freestnoe, as good as Elberta, stands shipping well, ripens about July 25th.

FITZGERALD-This peach comes in when other peaches are scarce, just after Elberta is ripe, is a good juicy yellow freestone.

HEALTH CLING-Is a good late white cling, tree hardy, not as sure to bear full crops as some but deserves a place as a late peach in every orchard, ripens last of September. ber.

INDIAN-A late red cling, medium sized, ripens in Septem-

SALWAY-Very late freestone, good yellow peach.

CHINESE CLING-Ripens in July, is as juicy as a peach can be, equally good for canning or pickling, is almost white, bears full crops when others fail.

CHAMPION-A white freestone, ripens about Aug. 20th, sweet, rich and juicy, skin creamy white with red cheek, it is hardy, productive, largest size and highest flavor.

CROSBY - A beautiful yellow freestone peach, very small pit, good flavor, large size, color orange-yellow, with carmine on sunny side, ripens just ahead of Crawford's Late.

\begin{tabular}{|c|c|c|c|}
\hline es & Each & 25 & 100 \\
\hline $\begin{array}{l}3 \text { to } 4 \\
31-2 \text { to } 5\end{array}$ & $\begin{array}{l}.20 \\
.25 \\
.30\end{array}$ & $\begin{array}{r}\$ 4.50 \\
6.00 \\
7.25\end{array}$ & $\begin{array}{r}\$ 16.00 \\
22.00 \\
28.00\end{array}$ \\
\hline
\end{tabular}

\section{Varieties of Cherry Trees}

EARLY RICHMOND-Medium sized, bright red, acid, very hardy and productive, fruits very young, for cooking and market amoung the best, ripens about June 20 th.

MONTMORENCY - King of sour cherries, fruit large bright red, fine flavor, very hardy and immense bearer, season a little later than Early Richmond. earlier.

DYE HOUSE-Like Early Richmond but ripens a few days

GOVERNOR WOOD-Large transparent colored cherry, hangs on trees well, ripens about with Montmorency, is a sweet cherry.

ENGLISH MORILLO-A late variety, bears young, medium sized, dark red, acid, very hardy, July.

$$
\text { Prices of Cherry. Trees }
$$

1 year old trees, 2 to 3 feet high $---2--\$$

2 year old trees, 3 to 4 feet high

2 year old trees, 4 to 5 feet high -... $\quad .75$

$\begin{array}{cc}25 & 100 \\ \$ 9.50 & \$ 36.00 \\ 13.00 & 48.00\end{array}$

\section{Varieties of Pear Trees}

KEIFFER-Is the best late pear for all purposes, very large, deep yellow with russet dots, ears young, most blight-proof pear of which we have any knowledge.

GARBER-Is larger and earlier than Keiffer, better flavor, bears young, keeps fairly well, ripens in September.

SECKEL-Small, finest flavor, excellent for preserving or dessert, very productive, ripens in August. 
BARTLETT-Is one of the largest sized pears, when fully ripe is of best quality, ripens the first of September, very juicy.

$$
\text { Prices of Pear Trees Each } 25 \quad 100
$$

1 year old trees, 2 to 3 feet high $\ldots \ldots \ldots \$ 30$. $\$ 6.25 \quad \$ 24.00$

1 year old trees, 3 to 4 feet high $\ldots . .-\quad .40 \quad 8.75 \quad 32.00$

\section{Varieties of Plum Trees}

BRADSHAW-Fruit very large, violet red, flesh yellowish green, juicy and pleasant, vigorous grower, August.

WILD GOOSE-American origin, medium sized red plum flesh juicy and sweet, July.

WICKSON-Japanesa origin, large, carmine color, stone small, flesh fine, sugary, good market sort, ripens in August.

YELLOW GOLD OR SHIRO-Japanese origin, tree a strong grower, wood hardy, fruit almost transparent color, flesh firm and juicy, rich hub-acid, cling-stone, July.

BURBANK-Japanese origin, flesh yellow, skin tough and tree hardy, one of best plums, ripens in July.

YELLOW EGG-Largest yellow plum, tree upright grower, should be set with wild goose to bear good, freestone, ripens in July.

\section{Prices of Plum Trees $\quad$ Each $25 \quad 100$}

1 year old trees, 2 to 3 feet high $\ldots \ldots-\$ .25 \quad \$ 6.00 \quad \$ 22.00$

1 year old trees, 3 to 4 feet high__._- $\quad .35 \quad 8.50 \quad 32.00$

2 year old trees, 3 to 5 feet high $\ldots-. .50 \quad .50 \quad 11.25 \quad 44.00$

\section{Nectorine and Apricot Trees}

BOSTON NECTORINE-Trees are as hardy as peach trees, fruit looks and tastes like apricots, has seed like plum, fruit about the size of large plums.

SUPERB APRICOT-New type from Kansas, very hardy, Russian origin, the best flavored apricot, ripens in August.

MOORPARK APRICOT-Very large yellowish green, with red on sunny side, freestone, fine for canning or drying, July 1st.

\section{Prices of Nectorine and Apricot Trees.}

1 year old trees, 2 to 3 feet high $\ldots \ldots \ldots .25, \$ 6.00 \quad \$ 22.00$ 1 year old trees, 3 to 4 feet high $\ldots . .-\quad .25 \quad 8.50 \quad 32.00$

COMPASS CHERRY-Originated in Minnesota, is a cross between Morelle cherry and Miner plum, remarkably hardy, planted extensively in northern states, hardy and fruitful, trees often have fruit on them in nursery rows, good for canning or any other purpose that plums are, July.

Sompass trees, 1 year old, 2 to 3 feet high, $30 \mathrm{c}$ each.

Compass trees, 2 years old, 3 to 4 feet high, $50 \mathrm{c}$ each.

ORANGE QUINCE-Large roundish yellow, cooks tender and of best quince flavor, for preserves or flavoring, September.

Quince trees, 2 year old, 3 to 4 feet high, $50 \mathrm{c}$ each.

\section{Grapes}

One of the easiest fruits grown, will do more with less care than any other fruit we know of; plant them in rows 7 feet each 
way and mulch down good in spring and be surprised at the amount of grapes you will get. First and best of all is Concard, the old standby, bunches large, compact, when fully ripe in August they are jet black, juicy and very sweet.

NIGARA - Said to be seedling of Concord, is a white grape and ripens with Concord, bunches large, berries sweet.

CAMPBELL'S EARLY-One of the best bluish-black early grapes, ripens in July, is sweet and juicy, very few seeds.

DELAWIARE-The bunches are small but compact, berry large, of Catawba color, thin skin, perfectly free from hard pulp, keeps well, early kind, ripening after Campbell's Early.

WOODRUFF-This grape has a peculiar flavor relished by many, is of reddish blue color, a handsome profitable market sort, bunches medium sized but berries large, long keeper, good shipper, this is my favorite table grape, ripens just before Concord, set some of this kind by all means.

PRICES OF GRAPE VINES.

Parcel-post

Prepaid

12

$\$ 1.00$

Concord, 1 year old,

Concord, 2 year old _....... 1.35

Niagara, 1 year old ........- 1.35

Niagara, 2 year old _....... 1.75

Campbell's, Each, 1 yr.....- 1.75

Delaware, 1 year old ........ 1.35

Woodruff, 1 year old ..... 1.35

\section{By express not} 25

$\$ 1.75$

2.50

2.50

3.50

3.50

2.50

2.50
100

$\$ 6.00$

9.00

9.00

13.00

13.00

9.00

9.00

\section{Blackberries}

Blackberries, next to grapes, do well on most any land if given a chance.

We recommend Early Harvest for early berries, they will ripen and be gone by the time dry weather sets in. They are small plump berries, good quality, prolific bearers.

SNIDER - The old standard, very hardy, consequently raised in cold climates, berries medium to largest size, juicy rich, strong stout canes, thrifty growth, heavy foilage.

ERIE-One of the best early berries we have, has large healthy canes, very productive, berries of jet black.

ELDORADO-A strong growing variety, very productive, fruit very large, jet black, in large clusters, ripens well together, its keeping qualities are unsurpassed, fine quality, sweet with no core.

One year old Early Harvest plants, 60c per 12 post-paid; 25 for $75 \mathrm{c} ; 100$ for $\$ 2.00$, not prepaid.

All other blackberry plants, 75e per 12, post-paid, 25 for $\$ 1.00 ; 100$ for $\$ 2.50$ not pre-paid.

\section{Raspberries}

CUMBERLAND_-"The business blackcap"-productive and hardy, bears heavy crops every year, largest berry we know of, extra stout, stocky canes, bears well any where.

PLUM FARMER-Is a large new black cap variety, new with us.

KANSAS-BLACKCAP-Firm and delicious, large and quite early, next to the best for this locality. 
CARDINAL-This new red variety originated in Kansas, quite prolific and hardy, has large berries, highly recommended.

ST. REGIS-A real everbearing variety of sterling merits, bears from June till frost, berries large and bandsome, sweet, usually bears a crop the year planted.

GOLDEN QUEEN-Very large, color rich yellow, vigorous, hardy, productive, splendid quality.

LOUDEN-This is the old standby red variety, upright canes, hardy, productive, best all-round market berry, perfectly firm.

\section{Prices on Raspberry Plants.}

12 plants postpaid

Kansas, Cumberland or Louden__-_- $\$ .75$

Cardinal, Plum Farmer and St. Regis.- .85

25 not postpaid $\$ 1.00$

1.25

1.50

Golden Queen _... 1.00

LUCRETIA DEWBERRY-Fruit very large, vines perfectly hardy, should be left lying on ground till spring when they should be lifted and staked up.

12 plants postpaid, $75 \mathrm{c}, 25$ plants, not postpaid, $\$ 1.00$.

CAREY'S THORNLESS DEWBERRY-This is a new berry originated by Luther Burbank, has not fruited for us yet but has been tested out in Ohio, Indiana, Iowa and other states and said to be hardy and to produce as well as Lucretia Dewberry, plants are absolutely thornless, grows runners about thre feet long each summer. Plants have proven hardy here for the last three win. ters. Price of tip plants, $10 c$, or 12 for $\$ 1.00$, postpaid.

HOUGHTON GOOSEBERRY-The old well known sort, pale red, sweet and good, it is rather small but reliable and productive. Goseberry plants, 1 year old, $15 \mathrm{c}, 12$ for $\$ 1.65$.

RED DUTCH CURRANTS-Old well-known sort, of good quality, great bearer, fine market variety, vigorous and upright grower. Currant plants, one year old, $15 \mathrm{c}, 12$ for $\$ 1.25$.

LOGANBERRY - Hybrid between a blackberry and red raspberry and produced in California, fruit as large as a blackberry, excellent as a novelty, does best in western states. Price of plants $10 \mathrm{c}, 12$ for $\$ 1.00$, post-paid.

RHUBARB - Mammoth red, best early kind, plants 10 cents each, or 12 for $\$ 1.00$ postpaid.

ASPARAGUS-Conover's Collasal-Best for general planting, price each, $5 \mathrm{c}$ or 12 for $50 \mathrm{c}$ post-paid.

\section{SPRING VARIETY OF STRAWBERRY PLANTS}

SENATOR DUNLAY-One of the best all-round sorts, has perfect blossom.

MITCHELL'S EARLY-One of the first to ripen and should be planted for this alone.

KLONDIKE-A good commercial berry, large, later than Mitchell or Dunlap, berry borne on long stems which hold them off the dirt.

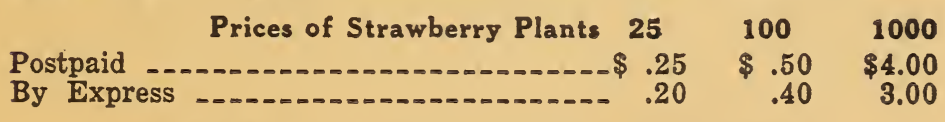

Progressive or Everbearing Strawberry Plants.

Postpaid _.

By Express postpaid; two year old trees, about three feet high, $10 \mathrm{c}$ each. NORWAY POPULAR-For shade trees, 2 to 3 feet high, 5c;

3 to 4 feet high, $10 \mathrm{c} ; 4$ feet and up, $12 \mathrm{c}$ each.

SOFT MAPLE-3 to 5 feet high, 20c each.

HARD MAPLE-3 to 5 feet high, $30 \mathrm{c}$ each. 
WHITE ASH-3 to 5 feet high, 25c each.

CATALA-Common flowering, 3 to 4 feet high, 20c each.

CATALA-Speciosia, 2 to 3 feet high, 20c each. each.

THORNLESS HONEY LOCUST-6 to 12 inches high, $5 \mathrm{c}$

Inquire for larger shade trees.

\section{SHRUBS AND OTHER FLOWER PLANTS}

(By Express)

Pink Flowering Ammon, blooming size -.............. $5 \mathrm{c}$

Althea, assorted colors, 2 to 3 feet high,

Calycanthus, 1 to 2 feet high .

Golden Bell, 2 feet high

Hydrangea, or Hills of Snow, 2 feet high

Purple Lilac, 2 feet high .....

White Lilac, 2 feet high

Mallow Marvel, pink, 2 year old

Snow Ball, 2 year old

Spirea, Balardi, Pink Flowers, 2 feet high

Spirea, Van Houttii, white flowers, 2 feet high

Wegelia, 2 feet high

Pink Dorothy Perkins rose bushes, 2 year old .......... 20c

White Dorothy Perkins rose bushes, 2 year old

Crimson Rambler rose bushes, 2 year old -.............- $35 \mathrm{c}$

La France rose bushes, 2 year old

General Jackson rose bushes, 2 year old

Snow Queen rose bushes, 2 year old

Cannas, Mixed colors............

Dahlias, mixed colors

Gladiolias, mixed colors, each $4 \mathrm{c}$; per dozen

Peonies, red, white and pink, 3 to 5 eyes

Boston Ivy, two year old

Wisteria, blue, one year old

Maderia Tubers, each $3 c$, or per dozen

White Crysanthemums, one year old _..............10c

EVERGREENS-Redi Cedar, 2 to 3 feet high, $20 \mathrm{c}$.

AMERICAN ARBOR-Vitae, 2 feet high, $7.5 \mathrm{c}$.

MUGHO PINE-Dwarf, 12 inches high, \$2.00.

CALIFORNIA PRIVET, 2 feet high, 15c each, or $\$ 12.00$ per 100. AMOOR PIVER PRIVET - 2 feet high, $17 \mathrm{c}$ each or $\$ 14.00$ per 100.

This includes the stock we try to grow and have on hands. Should you want other items please write us asking for prices, stating amount wanted.

P. S. This circular prepared by P. E. Cook, a man with 17 years experience growing and selling trees.

University of Missouri,

\section{Copy of Our In'spection Certificate.}

Agricultural Experiment Station,

Plant Inspection Service.

Columbia, Missouri, August 20, 1923.

CERTIFICATE OF NURSERY INSPECTION.

This is to certify that in accordance with the plant inspection act, passed by the forty-seventh General Assembly and ap. proved March 27, 1923, the nursery stock of the Home Nursery Co., J. E. Armstrong and P. E. Cook, Nursery grown at Liberal, Mo., was inspected on July 26,1923 , by a duly authorized inspector and found apparently free from dangerous or injurious insects or plant diseases.

Valid until July 1, 1924, unless sooner revoked.

$$
\text { L. HASEMAN, }
$$

Entomologist and Chief Inspector. 